\begin{tabular}{|c|c|}
\hline Title & The Rate of the Photoelectrochemical Generation of Hydrogen at p-Type Semiconductors \\
\hline Author(s) & Bockris, J. O 'M.; Uosaki, K. \\
\hline Citation & $\begin{array}{l}\text { Journal of The Electrochemical Society, 124(9), 1348-1355 } \\
\text { https://doi.org/10.1149/1.2133652 }\end{array}$ \\
\hline Issue Date & 1977 \\
\hline Doc URL & http:/hdl.handle.net/2115/50261 \\
\hline Rights & $\begin{array}{l}\text { () The Electrochemical Society, Inc. 1977. All rights reserved. Except as provided under U.S. copyright law, this work } \\
\text { may not be reproduced, resold, distributed, or modified without the express permission of The Electrochemical Society } \\
\text { (ECS). The archival version of this work was published in J. Electrochem. Soc. } 1977 \text { volume 124, issue 9, 1348-1355. }\end{array}$ \\
\hline Type & article \\
\hline File Information & JES1249_1348-1355.pdf \\
\hline
\end{tabular}

Instructions for use 


\section{The Rate of the Photoelectrochemical Generation of Hydrogen at $p$-Type Semiconductors}

J. O'M. Bockris and K. Uosaki

J. Electrochem. Soc. 1977, Volume 124, Issue 9, Pages 1348-1355.

doi: 10.1149/1.2133652

Email alerting Receive free email alerts when new articles cite this article - sign up in service the box at the top right corner of the article or click here

To subscribe to Journal of The Electrochemical Society go to: http://jes.ecsdl.org/subscriptions

(C) 1977 ECS - The Electrochemical Society 


\title{
The Rate of the Photoelectrochemical Generation of Hydrogen at p-Type Semiconductors
}

\author{
J. $O^{\prime} M$. Bockris* and K. Uosaki ${ }^{1}$ \\ School of Physical Sciences, Flinders University, Adelaide, Australia 5042
}

\begin{abstract}
The current-potential relations with and without illumination, quantum efficiency-wavelength relations at several potentials, the flatband potentials, the transient behavior, and the stability of seven $\mathrm{p}$-type semiconductors, i.e., $\mathrm{ZnTe}, \mathrm{CdTe}, \mathrm{GaAs}$, InP, GaP, SiC, and $\mathrm{Si}$, have been measured in $1 \mathrm{~N} \mathrm{NaOH}$ and $1 \mathrm{~N} \mathrm{H}_{2} \mathrm{SO}_{4}$. The position of the photocurrent-potential relations are related to the flatband potential and the energy gap of the semiconductor. The existence of the maximum in quantum efthciency-wavelength relation is analyzed by considering surface recombination. The stability and the transient behavior are analyzed.
\end{abstract}

Photoelectrochemical production of hydrogen was envisaged by Fujishima and Honda in 1972 (1). To obtain hydrogen, either a $\mathrm{pH}$ gradient or an external power source in the cell was required (2-4). However, homogenization of the solution would inevitably occur on prolonged functioning in such an arrangement.

The lack of need for single crystals in the photoelectrochemical approach to energy conversion $(5,6)$ gives the prospect of favorable economics in purely photoelectrochemical hydrogen production from water. The primary aim is the development of a suitable cathode, so that light may be directed both onto the cathode and anode, with the objective of obtaining stable photoelectrolysis in a cell with a uniform $\mathrm{pH}$. A previously reported photocathode is unstable (7). We report investigations concerning the stability and efficiency of certain new photocathodes.

\section{Experimental}

Apparatus.-The photoelectrochemical cell is shown in Fig. 1. Stopcocks and taps were Teflon. To avoid contact of the metal used to form an ohmic contact with the solution, the back face and side of the electrode were covered with epoxy resin. To minimize contact of this with the solution, a Teflon electrode holder was used. The absence of a leak was verified by the small magnitude of the dark current. All photoelectrode areas were $0.125 \mathrm{~cm}^{2}$.

A PAR Model 173 potentiostat/galvanostat, with a Model 176 current-potential converter, was used to control the potential. The electrode potential was swept by a Wenking SMP 69 potential stepping motor control. The current-potential relationship was recorded by a Hewlett-Packard Model 7004B X-Y recorder. The time dependence of the photocurrent was recorded by means of a Hitachi QD25 recorder.

A $900 \mathrm{~W}$ xenon lamp (Canrad-Hanovia 538C1) was used as a light source and a Jarrell-Ash quarter-meter grating monochrometer (Cat. no. 82-410) was employed to obtain monochromatic light. An IR absorbing filter (Oriel G-776-7100) was placed between the cell and the light house, when current-potential measurements were carried out without the monochrometer. However, a quartz lens $(d=5 \mathrm{~cm}, f=5 \mathrm{~cm}$ ) was employed to concentrate the light on the electrode surface when the photocurrent was measured under monochromatic light. In this case, two Iong pass filters (Oriel G-7723900 and Oriel G-772-5400) were used with an IR absorbing filter to eliminate second-order diffraction. The conditions used in this respect were: $3000 \sim 5000 \AA, I R$

* Electrochemical Society Active Member.

1 Present address: Mitsubishi Petrochemical Company, Limited, Ami, Ibaraki, Japan.

Key words: hydrogen production, photoelectrochemical reaction, p-type semiconductors, photocathodes. absorbing filter only; $5000 \sim 7000 \AA, I R$ absorbing filter + G-772-3900 filter; $7000 \sim 7500 \AA$, IR absorbing filter + G-772-5400 filter; $7500 \AA, \mathrm{G}-772-5400$ filter only.

The intensity of light was measured by means of a Hewlett-Packard Model 8334 radiant flux meter with either a $8334 \mathrm{~A}$ radian flux detector or a Carl Zeiss vacuum thermocouple (VT Q3/A) with a Keithley 149 millimicrovoltmeter. The error in relative intensity measurement was $<5 \%$. However, absolute intensity measurements had an uncertainty of $\pm 20 \%$ error.

The electrochemical cell and the optical system were set up on an optical bench.

Impedance measurement.-The cell for impedance measurements had a working electrode surrounded by a cylindrical platinized platinum counterelectrode, apparent area $60 \mathrm{~cm}^{2}$. Hydrogen gas was passed into the solution before and during measurement.

The direct method was employed $(8,9)$. The circuit contained a dry cell $(6 \mathrm{~V})$ as a d-c source and the potential was controlled by a ten-turn variable resistor

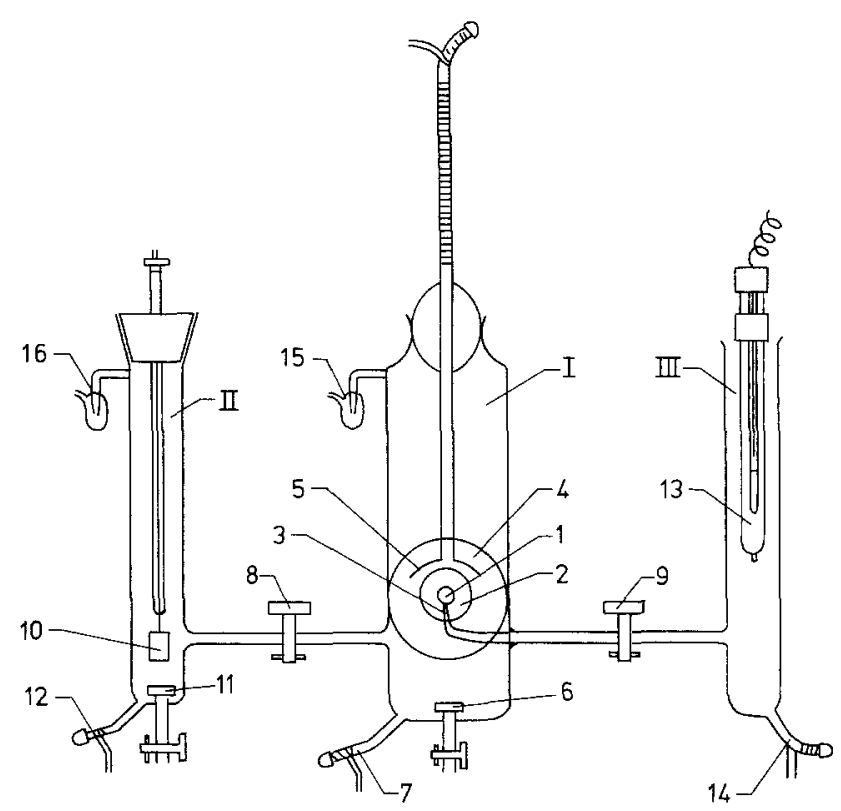

Fig. 1. The photoelectrochemical cell (front view). 1, Working electrode compartment $(d=50 \mathrm{~mm})$; II, counterelectrode compartment $(d=25 \mathrm{~mm})$; III, reference electrode compartment ( $d$ $=20 \mathrm{~mm}$ ). 1, Working (ssmiconductor) electrode; 2, Teflon electrode holder; 3, Luggin capillary; 4, quartz optical flat; 5, gas collector; 6, 11, frits (gas inlets); 7, 12, 14, drains; 8, 9, Teflon stopsocks; 10, Pt counterelectrode; 13 , reference electrode (SCE); 15, 16, gas bubbler. 
while being monitored by means of a Keithley 616 digital electrometer. The a-c source was a Mini-Lab Model 603A (B.W.D. Electronics). A capacitor $(10 \mu \mathrm{f})$ and a choke coil $(35 \mathrm{H})$ were in the circuit. The resistor, the value of which was several hundred times larger than the cell impedance, $Z_{\text {cell, }}$, was connected in series to the cell so that the alternating current, $I$, became constant, and independent of the cell voltage. The impedance of the choke was at least one hundred times larger than that of the cell.

Signals taken from two points in the circuit and applied to the $X$ and $Y$ inputs of a cathode ray oscilloscope (Tetronix $5103 \mathrm{~N}$ with $5 \mathrm{~A} 20 \mathrm{~N}$ and $5 \mathrm{~A} 2 \mathrm{IN}$ differential amplifiers) displayed Lissajou's figures. Since the $X$ and $Y$ inputs showed $I\left(Z_{\text {cell }}+R\right)$ and $I Z_{\text {cell, }}$ respectively, and $R>Z_{\text {cell }}$, the absolute value of the cell impedance, and phase difference due to the cell, could be ascertained. Assuming a series equivalent circuit (measurements were carried out under nearly ideally polarized conditions), the cell capacitance, which is effectively the space charge capacitance of the semiconductor electrode, can be obtained.

The accuracy of the direct method is low compared with that of the bridge method $(8,9)$. At metal electrodes the phase difference is small, and hence determination of $C$ is inaccurate by this method.

However, at semiconductor electrodes, capacitance is low so that the phase difference can be measured accurately.

Semiconductors chosen.-Cathodes were selected on the basis of sufficiently low values of energy gap (2.574 $\left.E_{\mathrm{G}}<1.3 \mathrm{eV}\right)$ and electron affinity $\left(E_{\mathrm{a}}<4.0 \mathrm{eV}\right)(28)$ Zinc telluride ( $\mathrm{ZnTe}$ ).-A $\mathrm{ZnTe}$ single crystal (Ag doped), grown by the Bridgeman method, was cut parallel to the cleaved face (100). After being etched in $\mathrm{K}_{2} \mathrm{Cr}_{2} \mathrm{O}_{7}-\mathrm{HNO}_{3}$ aqueous solution, the specimen was dipped in $\mathrm{HAuCl}_{4}$ solution to make an ohmic contact (10). It was masked with paraffin, later removed in trichloroethylene. The contact was ohmic and the specific resistance was $0.2 \Omega \cdot \mathrm{cm}$. The face of the specimen was polished by means of emery paper to 600 grade. The electrode was etched in $\mathrm{HF}-\mathrm{HNO}_{3}$ (11) solution.

Cadmium telluride (CdTe).-A CdTe single crystal (undoped) grown by the Bridgeman method was cut parallel to the cleaved face (100). The specimen was heated in Te vapor at $500^{\circ} \mathrm{C}$ for $8 \mathrm{hr}$ to increase nonstoichiometry. Thereafter, the crystal was etched in $\mathrm{K}_{2} \mathrm{Cr}_{2} \mathrm{O}_{7}-\mathrm{HNO}_{3}$ (12), dipped into $\mathrm{AgNO}_{3}$ solution, and heated at $200^{\circ} \mathrm{C}$ for $30 \mathrm{~min}$. Finally, a gold film was grown on the crystal by dipping it into aqueous $\mathrm{HAuCl}_{4}$ (13). During the processes of etching and dipping into $\mathrm{AgNO}_{3}$ and $\mathrm{HAuCl}_{4}$ solutions, the crystal was covered with paraffin except for the spots where it was intended to make a contact. The specific resistance was $10^{3}$ $\Omega \cdot \mathrm{cm}$ and the ohmic character of the contact good. The face to be used was polished by emery paper, 400 to 600 grade, and the surface etched in $\mathrm{HF}-\mathrm{HNO}_{3}$ solution.

Gallium arsenide (GaAs).-The GaAs was a single crystal in wafer form, (100) face; $\mathrm{Zn}$ doped; carrier density $=2 \times 10^{19} \mathrm{~cm}^{-3} ; 0.5 \mathrm{~mm}$ thick. It was etched (12) by dipping into $\mathrm{CH}_{3} \mathrm{OH}-\mathrm{Br}_{2}(5 \%)$ solution, for 1 min before an ohmic contact was made by soldering with indium (14). The $I-V$ relation was ohmic. The specific resistance was $0.2 \Omega \cdot \mathrm{cm}$.

Indium phosphide (InP).-The InP was a single crystal wafer (100) face, $Z n$ doped; carrier density $5.6 \times 10^{18}$ $\mathrm{cm}^{-3} ; 0.8 \mathrm{~mm}$ thick. Treatment was as for GaAs except that the ohmic contact was by means of an In-Zn alloy (15). The specific resistance was $0.21 \Omega \cdot \mathrm{cm}$.

Gallium phosphide ( $\mathrm{GaP}$ ).-The GaP was a single crystal wafer, $\mathrm{Zn}$ doped; carrier density $6.7 \times 10^{17}$ $\mathrm{cm}^{-3}$; (111) face; $0.4 \mathrm{~mm}$ thick. $\mathrm{A} \mathrm{HNO}_{3}-\mathrm{HCl}$ mixture was used for etching (12). An ohmic contact was obtained by the use of an In-Zn alloy (7). The specific resistance was $2.0 \Omega \cdot \mathrm{cm}$.
Silicon carbide ( $\mathrm{SiC}$ ).-The silicon carbide was a single crystal; $(000 \overline{1})$ face; Al doped; carrier density $4 \times 10^{18}$ $\mathrm{cm}^{-3} ; 0.2 \mathrm{~mm}$ thick. "Acme" conductive adhesive gave an ohmic contact if heated in hydrogen at $300^{\circ} \mathrm{C}$ for $2 \mathrm{hr}$. The specific resistance was $0.31 \Omega \cdot \mathrm{cm}$. The electrode was dipped in $\mathrm{HF}$ for $1 \mathrm{~min}$ before each experiment.

Silicon (Si).-The silicon was a single crystal wafer, (100) face; $B$ doped; $0.2 \mathrm{~mm}$ thick. An In-Zn alloy was used to obtain an ohmic contact. The specific resistance was $1.2 \Omega \cdot \mathrm{cm}$. The crystal was etched in $\mathrm{HF}$ solution before each experiment.

\section{Results}

The current-potential relations.-The current-potential relations with and without illumination by means of a $900 \mathrm{~W}$ Xe lamp were measured in $1 \mathrm{~N} \mathrm{NaOH}$ and in $1 \mathrm{~N} \mathrm{H}_{2} \mathrm{SO}_{4}$. The relations found can be divided into two groups. Results typical of the first group ( $\mathrm{ZnTe}$, $\mathrm{CdTe}, \mathrm{GaP}^{2} \mathrm{SiC}$, and $\mathrm{Si}$ ) are exemplified in Fig. 2 ( $\mathrm{Zn}$ Te). Dark curents are low. Typical results of the second group (GaAs and InP) are in Fig. 3 (GaAs). ${ }^{2}$ The degree of displacement of the current-potential

2 In the measurements of Gerischer et al. (16), GaAs showed saturation photocurrents at $-1.0 \mathrm{~V}$, but such saturation was not observed in our work, probably due to a lower intensity of illumination. The current-potential curves observed for GaP were similar to those reported earlier by other workers (17-19)

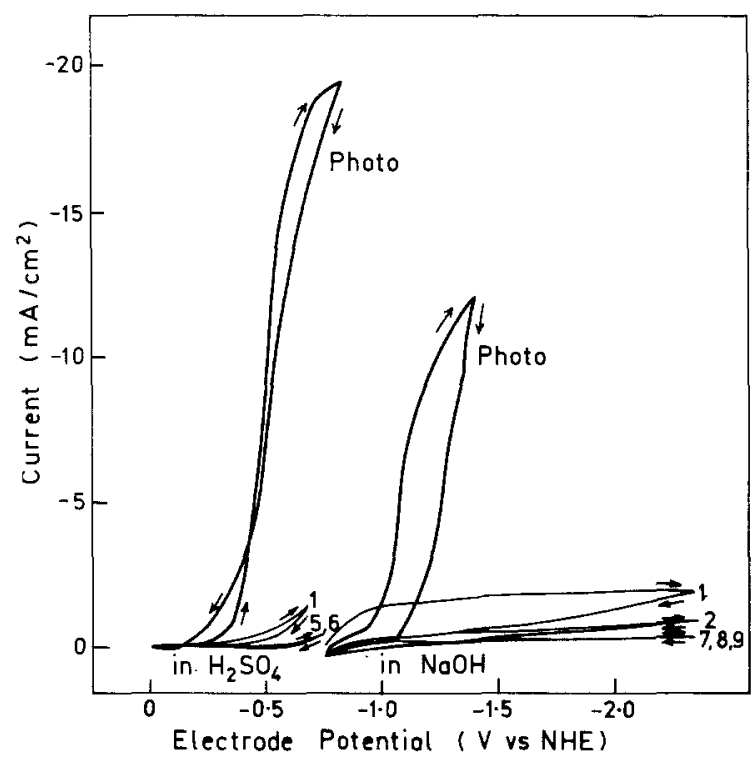

Fig. 2. The current-potential relations of $\mathrm{ZnTe}$ in $\mathrm{IN} \mathrm{NaOH}$ and IN $\mathrm{H}_{2} \mathrm{SO}_{4}$ with and without illumination by a $900 \mathrm{~W} \mathrm{Xe}$ lamp. Sweep rate: $1.5 \mathrm{~V} / \mathrm{min}$. Intensity of light $0.08 \mathrm{~W} / \mathrm{cm}^{2}$. Arrows show the direction of the polarization. 1, 1st sweep in dark; 2, 2nd sweep in dark. 5, 6, 7, 8, 9, 5th, 6th, 7th, 8th, and 9 th sweeps in dark.
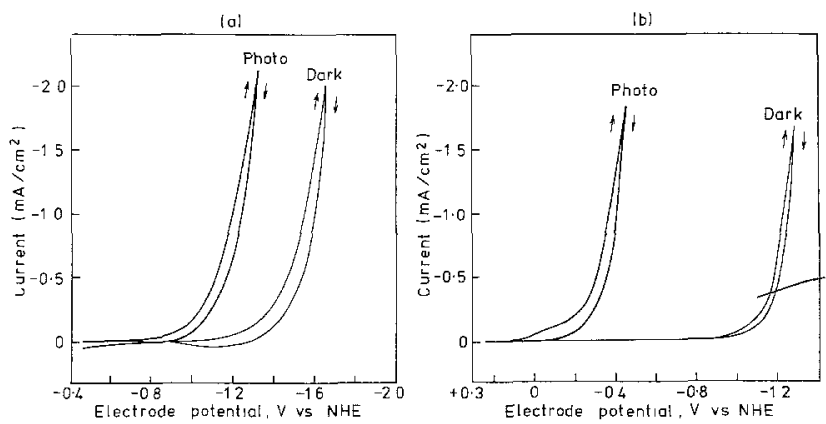

Fig. 3. The current-potential relations of $\mathrm{GaAs}$ with and without illumination by a 900 Xe lamp in $1 \mathrm{~N} \mathrm{NaOH} \mathrm{(a)} \mathrm{and} 1 \mathrm{~N} \mathrm{H}_{2} \mathrm{SO}_{4}$ (b). Sweep rate: $1.5 \mathrm{~V} / \mathrm{min}$. Intensity of light: $0.08 \mathrm{~W} / \mathrm{cm}^{2}$. 
curves in $\mathrm{H}_{2} \mathrm{SO}_{4}$ and $\mathrm{NaOH}$ respectively is shown in Table I.

At CdTe in $\mathrm{NaOH}$ no photocurrent was observed at a potential more positive than $-0.75 \mathrm{~V}$, when the oxygen concentration in the solution had been sufficiently diminished.

A white film was observed on the InP electrode after measurements in $1 \mathrm{~N} \mathrm{H}_{2} \mathrm{SO}_{4}$. Mayumi et al. (20) observed such white films: Irreproducibility due to them may account for the fact that the critical potential observed by Mayumi was $0.5 \mathrm{~V}$ more negative than that reported here. No films were observed in $1 \mathrm{~N} \mathrm{NaOH}$.

Photocurrents at SiC electrodes were $<10 \mu \mathrm{A} \mathrm{cm}^{-2}$.

Quantum efficiency-wavelength relations at several potentials.-Photocurrents were measured under monochromatic light at several potentials. Quantum efficiencies were calculated by using measured values of the photocurrents and the light intensity. Typical results are shown in Fig. 4 (GaP). ${ }^{3}$ The spectral response of the quantum efficiency in $1 \mathrm{~N} \mathrm{NaOH}$ of the semiconductors examined in this work except for $\mathrm{GaP}$ and $\mathrm{SiC}$ are shown in Fig. 5. Those in $1 \mathrm{~N}_{2} \mathrm{SO}_{4}$ are as in $1 N$ $\mathrm{NaOH}$. Quantum efficiencies at $\mathrm{SiC}$ in $1 N \mathrm{NaOH}$ (Fig. 6) are low.

The flatband potential.-The flatband potentials were determined by using Mott-Schottky plots. A typical plot is shown in Fig. 7 (SiC). Table II shows the flatband potential of the semiconductors in $1 N \mathrm{NaOH}$ and $1 N \mathrm{H}_{2} \mathrm{SO}_{4}$ and the slopes of the corresponding MIottSchottky plot. The flatband potentials of InP in $1 \mathrm{~N}$ $\mathrm{H}_{2} \mathrm{SO}_{4}$ and $\mathrm{Si}$ in $1 \mathrm{~N} \mathrm{NaOH}$ and $1 \mathrm{~N} \mathrm{H}_{2} \mathrm{SO}_{4}$ could not be measured due to the instability of these materials in solution.

Gleria and Memming reported (22) difficulties in respect to the Mott-Schottky plot on SiC but none were noted here.

Transient measurement-Current-time relations at fixed potentials following illumination and interruption of light were measured in $1 \mathrm{~N} \mathrm{NaOH}$ and $1 \mathrm{~N} \mathrm{H}_{2} \mathrm{SO}_{4}$. Typical results are in Fig. 8. When the potential is relatively negative, the current becomes stable just after the light was on or off, but when the electrode potential became relatively positive, it took time to attain a steady state (Fig. 8d).

Stability.-The photocurrents at fixed potentials were measured as a function of time $(1-20 \mathrm{hr})$ at all semiconductors mentioned above in $1 \mathrm{~N} \mathrm{NaOH}$ and $1 \mathrm{~N}$ $\mathrm{H}_{2} \mathrm{SO}_{4}$. Results are listed in Table III in terms of $(1 / i)(d i / d t)$, which is a measure of the instability.

\section{Discussion}

By analogy to well-known behavior at the metalvacuum interface, the electrode potential corresponding to the commencement of electron emission ("the critical potential") would have been expected to vary with change of the frequency of the exciting source. That the critical potential is not thus dependent for the semiconductor-solution interface is demonstrated in Fig. 9 ( $\mathrm{Zn}$ Te). An interpretation is that electronphonon collisions in the semiconductor cause the electrons photogenerated within the semiconductors at various energies (depending on the wavelength of the

3 Reasonable agreement was observed with the results of Yoneyama et al. (21), but the maximum in the quantum efficiencywavelength relation was at $4500 \AA$ in their measurement and at $3500 \AA$ in ours. In the Yoneyama work, published data on xenon lamps (instead of calibration) was used.

Table 1. The difference in the range of potentials (volts) for photocurrent-voltage relations in $\mathrm{NaOH}$ and $\mathrm{H}_{2} \mathrm{SO}_{4}$

$\begin{array}{lc}\text { ZnTe } & 0.6 \\ \text { CdTe } & 0.5 \\ \text { GaAs } & 0.8 \\ \text { InP } & 0.5 \\ \text { GaP } & 0.6 \\ \text { SiC } & \text { Not applicable } \\ \text { Si } & 0.5\end{array}$

incident light) to fall to the bottom of the conduction band before they have reached the electrode surface.

The $i_{\text {photo }}-V$ relations are Tafel-like (Table IV), whereas, at metals, $i^{0.4}$ is linear with $V$. Thus, in metals, nearly all the photoactivated electrons decay before the surface is reached. The small fraction $(<$ $10-2 \%$ ) of photoactivated electrons which reach the surface and emit have an energy distribution which is a function of the energy of the exciting source. In the semiconductor, a greater fraction $(\sim 1 \%)$ of the photogenerated electrons reaches the surface but the energy of nearly all of them is that of the conduction band, Fig. 10. (See above). The variation of the electrochemical photocurrent with potential then becomes subject to the reasoning [e.g., Ref. (23)] which relates the thermal current to potential at metals.

The saturation part of the photocurrent-potential relation can be understood from Fig. 11. When the electrode potential is such that the energy of the emitting electrons is equal to that of the ground state of the acceptor levels in $\mathrm{H}_{3} \mathrm{O}^{+}$, no further increase in the availability of acceptor levels in solution occurs as the potential is made more negative (24).
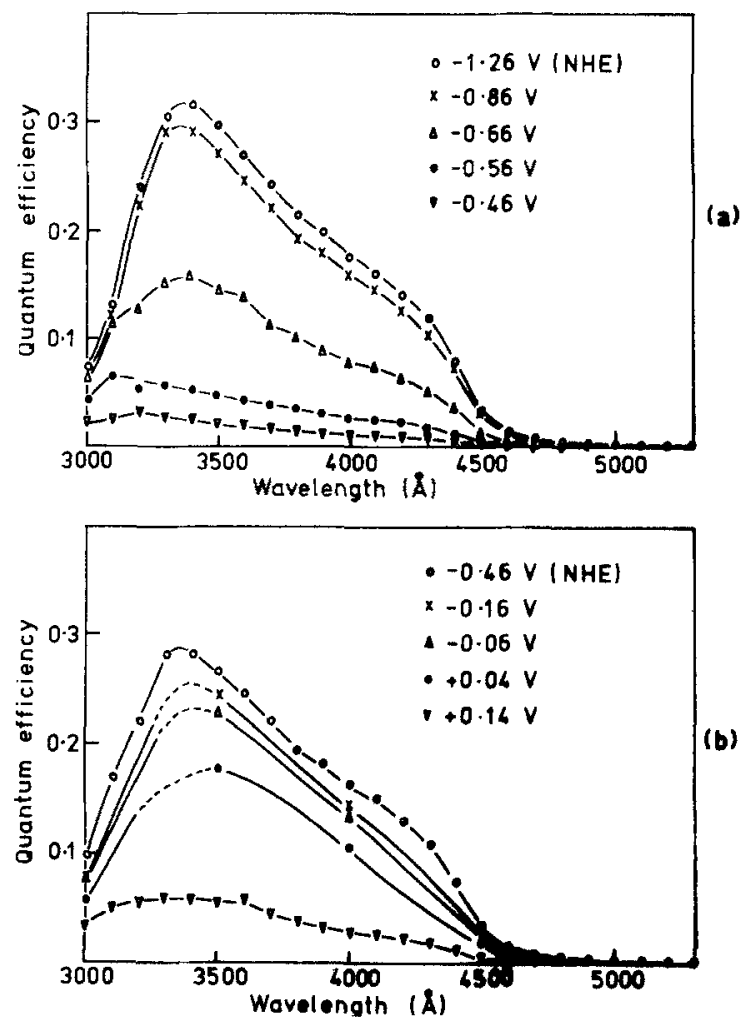

Fig. 4. The quantum efficiency-wavelength relations of $\mathrm{GaP}$ in i $\mathrm{NaOH}$ (a) and $1 \mathrm{~N} \mathrm{H}_{2} \mathrm{SO}_{4}$ (b) at several electrode potentials.

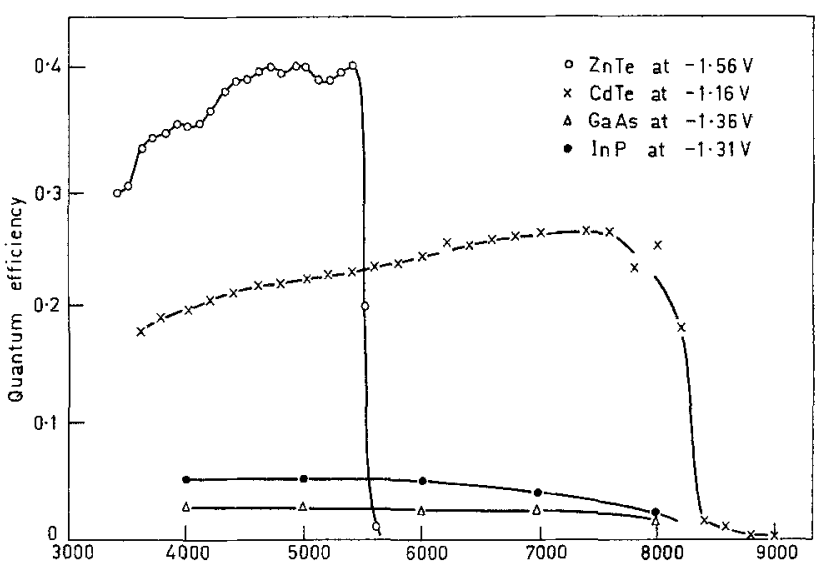

Fig. 5. The quantum efficiency wavelength relations for $\mathrm{ZnTe}$ CdTe, GaAs, and InP in IN NaOH. 
The "critical potential" $-\Delta H$ '(e) (Fig. 12) at the flatband potential is given by (23)

$$
\Delta H^{\prime}(e)=-L_{\mathrm{o}}+E_{\mathrm{a}}-J+A+R+\left(\mathrm{s.c}_{\Delta} \mathrm{s}_{\phi}\right)_{\mathrm{fbp}}[1]
$$

where $L_{0}, E_{\mathrm{a}}, J, A, R$, and $\left(\mathrm{S}^{\mathrm{S}} \mathrm{c}_{\Delta} \mathrm{s}_{\phi}\right)$ fhp are the hydration energy of the proton, electron-affinity of the semiconductor, ionization energy of hydrogen, adsorption en-
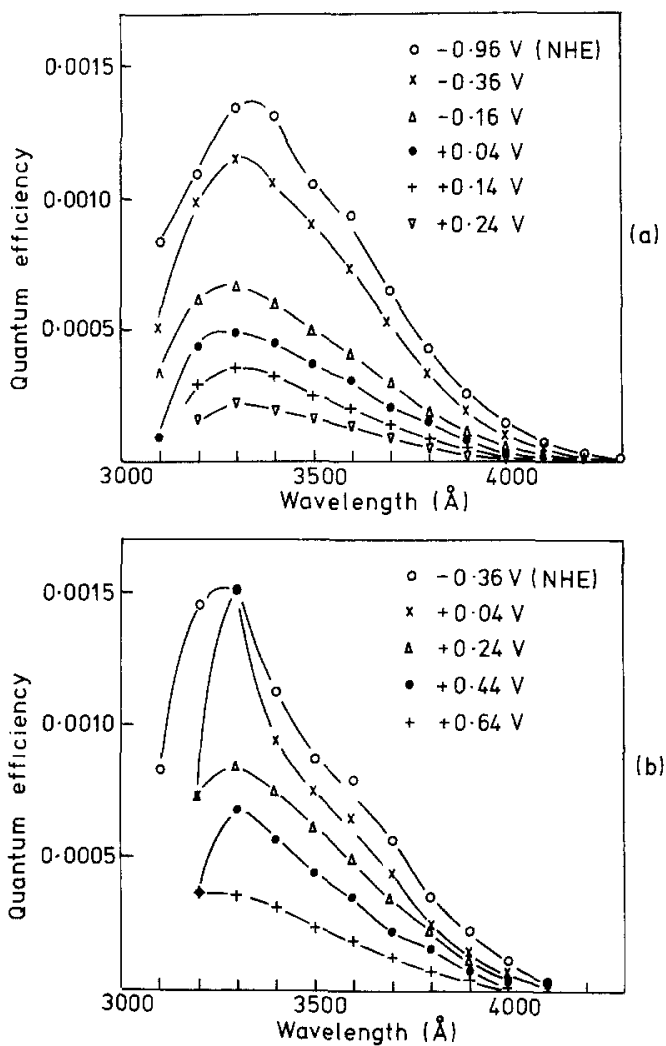

Fig. 6. The quantum efficiency-wavelength relations of $\mathrm{SiC}$ in IN NoOH (a) and $1 \mathrm{~N} \mathrm{H}_{2} \mathrm{SO}_{4}$ (b).
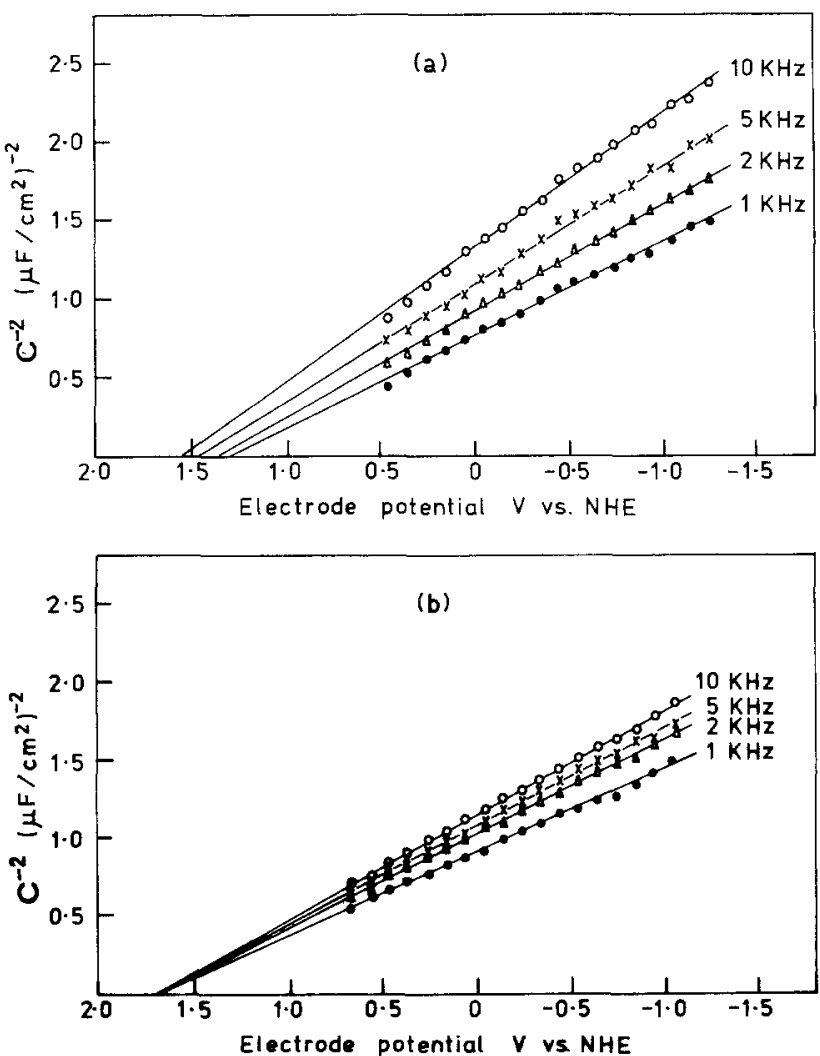

Fig. 7. The Mott-Schottky plots of $\mathrm{SiC}$ in $\mathrm{IN} \mathrm{NaOH} \mathrm{(a)} \mathrm{and}$ $1 \mathrm{~N} \mathrm{H}_{2} \mathrm{SO}_{4}$ (b) at several trequencies.
Table II. The flatband potential and slope of Mott-Schottky plots of semiconductors

\begin{tabular}{|c|c|c|c|c|}
\hline \multirow[b]{2}{*}{$\begin{array}{l}\text { Semicon- } \\
\text { ductors }\end{array}$} & \multicolumn{2}{|c|}{$1 N \mathrm{NaOH}$} & \multicolumn{2}{|c|}{$1 \mathrm{~N} \mathrm{H}_{2} \mathrm{SO}_{4}$} \\
\hline & $\begin{array}{l}\text { Flatband } \\
\text { potential, } \\
\text { V, NHE }\end{array}$ & $\begin{array}{c}\text { Slope } \\
(\mu \mathrm{f} / \\
\left.\mathrm{cm}^{2}\right)^{-2} / \mathrm{V}\end{array}$ & $\begin{array}{l}\text { Flatband } \\
\text { potential, } \\
\text { V, NHE }\end{array}$ & $\begin{array}{c}\text { Slope } \\
(\mu \mathbf{f} / \\
\left.\mathrm{cm}^{2}\right)^{-2} / \mathrm{V}\end{array}$ \\
\hline $\begin{array}{l}\text { ZnTe } \\
\text { CdTe } \\
\text { GaAs } \\
\text { InP } \\
\text { GaP } \\
\text { SiC }\end{array}$ & $\begin{array}{r}-0.79 \\
0.21 \\
-0.04 \\
-0.07 \\
0.18 \\
1.38\end{array}$ & $\begin{array}{l}28 \\
6000 \\
0.12 \\
0.48 \\
6.0 \\
0.86\end{array}$ & $\begin{array}{r}0.04 \\
-0.35 \\
0.43 \\
1.13 \\
1.68\end{array}$ & $\begin{array}{c}150 \\
2200 \\
0.22 \\
4.6 \\
0.7\end{array}$ \\
\hline
\end{tabular}

ergy of hydrogen, $\mathrm{H}-\mathrm{H}_{2} \mathrm{O}$ repulsive force, and the potential drop in the electric double layer at the flatband potential.

$\left(\mathrm{S}^{\mathrm{C}} \mathrm{C}_{\Delta} \mathrm{S}_{\phi}\right)_{\text {fbp }}$ can be estimated as follows.

The flatband potential, $V_{\text {fbp }}$, with respect to normal hydrogen electrode (NHE) is given by

$$
V_{\mathrm{fbp}}={ }^{\mathrm{Pt}} \Delta \mathrm{S}^{\mathrm{S} \cdot \mathrm{C}_{\phi}}+\left(\mathrm{S}^{\mathrm{S}} \mathrm{C}_{\Delta} \mathrm{S}_{\phi}\right)_{\mathrm{fbp}}+\left(\mathrm{S}_{\Delta} \mathrm{Pt}_{\phi}\right)_{p_{\mathrm{H}_{2}=1}=1}
$$

where $\mathrm{Pt}_{\Delta} \mathrm{S}_{\mathrm{S}} \mathrm{C}_{\phi}$ is the potential difference between the semiconductor and the Pt wire, $\left({ }^{\mathrm{S}} \Delta^{\mathrm{Pt}} \phi\right)_{\mathrm{C}_{\mathrm{H}^{+}}=1}$ is the potential drop in the electric double layer of the semiconductor at the flatband potential and $\left(\mathrm{S}_{\Delta} \mathrm{Pt}_{\phi}\right)_{\mathrm{C}_{\mathrm{H}_{2}=1}}$ is the potential drop in the electric double layer at the $\mathrm{Pt}$ electrode in the presence of 1 atm of hydrogen gas and with $C_{H^{+}}=1$. (See Fig. 12).

Since

$$
\mu_{\mathrm{e}}{ }^{-\mathrm{Pt}}=\mu_{\mathrm{e}}-\mathrm{S} . \mathrm{C}
$$

where $\mu_{\mathrm{e}}^{-\mathrm{Pt}}$ and $\mu_{\mathrm{e}}-\mathrm{S.C}$ are the electrochemical potentials of electrons in $\mathrm{Pt}$ and the semiconductor, respectively. Hence

$$
\mathrm{Pt}_{\Delta}{\mathrm{S} . \mathrm{C}_{\phi}}=\left(\mu_{\mathrm{e}}^{\mathrm{Pt}}-\mu_{\mathrm{e}}^{\mathrm{S} . \mathrm{C}}\right) / \mathrm{F}
$$

where $\mu_{\mathrm{e}}^{\mathrm{Pt}}$ and $\mu_{\mathrm{e}}^{\mathrm{S.C}}$ are the chemical potentials of $\mathrm{Pt}$ and the semiconductor, respectively. Therefore

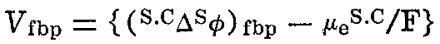

$$
\begin{aligned}
& -\left[\left(\mathrm{Pt}^{\Delta^{\mathrm{S}} \phi}\right)_{\substack{\mathfrak{C}_{\mathrm{H}_{2}=1}=1 \\
\mathbf{H}^{+}=1}}-\mu_{\mathrm{e}}^{\mathrm{Pt}} / \mathrm{F}\right]
\end{aligned}
$$
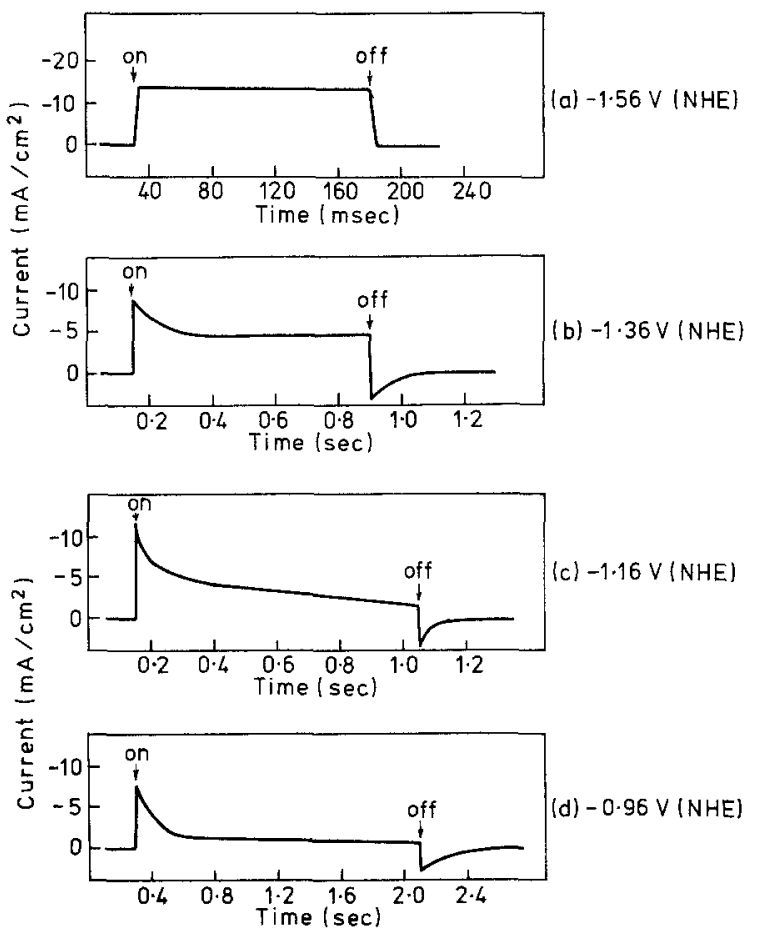

Fig. 8. The transient behavior of the current of $\mathrm{ZnTe}$ after illumination and interruption of light in $1 \mathrm{~N} \mathrm{NaOH}$ at several potentials. The current before illumination is taken as zero. Intensity of light: $0.08 \mathrm{~W} / \mathrm{cm}^{2}$. 
Table III. The stability of photocathodes, as measured by their change with time at various potentials (given)

\begin{tabular}{|c|c|c|}
\hline \multirow{2}{*}{$\begin{array}{l}\text { Semicon- } \\
\text { ductor }\end{array}$} & \multicolumn{2}{|c|}{ Value of $\frac{1}{i} \frac{d i}{d t}\left(\sec ^{-1}\right)$} \\
\hline & $1 N \mathrm{NaOH}$ & $1 \mathrm{~N} \mathrm{H}_{2} \mathrm{SO}_{4}$ \\
\hline $\begin{array}{l}\text { ZnTe } \\
\text { CdTe } \\
\text { GaAs } \\
\text { InP } \\
\text { GaP } \\
\text { SiC } \\
\text { Si }\end{array}$ & $\begin{array}{l}6 \times 10^{-4}(-1.26 \mathrm{~V}) \\
2.5 \times 10^{-6}(-1.16 \mathrm{~V}) \\
2 \times 10^{-4}(-1.36 \mathrm{~V}) \\
2 \times 10^{-5}(-1.36 \mathrm{~V}) \\
5 \times 10^{-5}(-0.76 \mathrm{~V}) \\
0^{*}(-1.16 \mathrm{~V}) \\
5 \times 10^{-6 * *}(-1.06 \mathrm{~V})\end{array}$ & $\begin{array}{l}5 \times 10^{-5}(-0.56 \mathrm{~V}) \\
1 \times 10^{-6}(-0.76 \mathrm{~V}) \\
3 \times 10^{-4}(-0.76 \mathrm{~V}) \\
2 \times 10^{-4}(-046 \mathrm{~V}) \\
5 \times 10^{-5}(-0.26 \mathrm{~V}) \\
0^{*}(-0.76 \mathrm{~V}) \\
1.7 \times 10^{-1 \neq *}(-0.41 \mathrm{~V})\end{array}$ \\
\hline
\end{tabular}

- Current is very small $9 \mu \mathrm{A} / \mathrm{cm}^{2}$ in $1 N \mathrm{NaOH}$ and $3 \mu \mathrm{A} / \mathrm{cm}^{2}$ in $1 \mathrm{~N} \mathrm{H}_{2} \mathrm{SO}_{4}$

** After $10 \mathrm{hr}$ in dark, almost no photocurrent was observed.

Thus, the potential drop in the electric double layer of the semiconductor at the flatband potential is given by

$$
\begin{aligned}
& \left(\mathrm{S}^{\mathrm{S}} \mathrm{C}_{\Delta} \mathrm{S}_{\phi}\right)_{\mathrm{fbp}}=V_{\mathrm{fbp}}+\left[\left(\mathrm{Pt}_{\Delta} \mathrm{S}_{\phi}\right)_{\substack{\mathrm{pH}_{2}=1 \\
\mathrm{C}_{\mathrm{H}^{+}=1}}}-\mu_{\mathrm{e}}^{\mathrm{Pt} / \mathrm{F}]}+\mu_{\mathrm{e}} \mathrm{S} \cdot \mathrm{C} / \mathrm{F}\right. \\
& =V_{\mathrm{fbp}}+\left[\left(\mathrm{Pt}_{\Delta} \mathrm{S}_{\phi}\right)_{\mathrm{C}_{\mathrm{H}_{2}=1}=1}-\mu_{\mathrm{e}}{ }^{\mathrm{Pt}} / \mathrm{F}\right] \\
& -\left(\Phi / F-\chi^{S . C}\right)
\end{aligned}
$$

where $\Phi$ is the work function of the semiconductor and $\chi^{\text {S.C }}$ is potential drop in the semiconductor.

$$
\left[\left({ }^{\mathrm{Pt}} \Delta^{\mathrm{S}} \phi\right)_{\mathrm{C}_{\mathrm{H}^{+}}=1}-\mu_{\mathrm{e}} \mathrm{pt}^{\mathrm{Pt} / \mathrm{F}}\right]
$$

was calculated by Trasatti (25) using a method suggested by Bockris and Argade (26), as 4.3V. Therefore

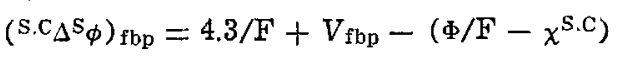

A schematic of the energy levels of a semiconductor which has surface states in a vacuum is shown in Fig. 13. From this figure, $\chi^{\mathrm{s.C}}$ is given by

$$
\mathrm{F} \chi^{\mathrm{S} . \mathrm{C}}=\Phi+\Delta E-E_{\mathrm{a}}-E_{\mathrm{g}}
$$

where $\Delta E$ is the energy difference between the Fermi level and the top of the valence band in the bulk. Hence, Eq. [7] becomes

$$
\left(\mathrm{S}^{\mathrm{C}} \mathrm{C}_{\Delta} \mathrm{S}_{\phi}\right)_{\mathrm{fbp}}=4.3 / \mathrm{F}+V_{\mathrm{fbp}}-\left(E_{\mathrm{a}}+E_{\mathrm{g}}-\Delta E\right) / \mathrm{F} \quad \text { [9] }
$$

As a first approximation, $\Delta E$ is assumed to be zero for all p-type semiconductors concerned.

The values of $\left(\mathrm{S}^{\mathrm{S}} \mathrm{C}_{\Delta} \mathrm{S}_{\phi}\right)_{\text {fbp }}$ were calculated from Eq. [9] for semiconductors listed in Table V. (s.. $\left.c_{\Delta} \mathbf{s}_{\phi}\right)_{f b p}$ is negative in all cases, s. $_{\Delta} \mathrm{S}_{\phi}$ in $\mathrm{NaOH}$ is more negative than that in $\mathrm{H}_{2} \mathrm{SO}_{4}$ for most electrodes except CdTe.

From Eq. [1] and [9]

\begin{tabular}{|c|c|c|}
\hline & $1 N \mathrm{NaOH}$ & $1 \mathrm{~N} \mathrm{H}_{2} \mathrm{SO}_{4}$ \\
\hline $\begin{array}{l}\mathrm{ZnTe} \\
\text { GaAs } \\
\text { GaP } \\
\text { CdTt }\end{array}$ & $\begin{array}{l}0.165 \\
0.3 \\
0.1\end{array}$ & $\begin{array}{l}0.13 \\
0.25 \\
0.18\end{array}$ \\
\hline $\mathrm{Si}$ & 0.17 & 0.21 \\
\hline
\end{tabular}

$$
\begin{aligned}
& \Delta H(e)=-L_{\mathrm{o}}+E_{\mathrm{a}}-J+A+R+4.3 / \mathrm{F} \\
&+V_{\mathrm{fbp}}-\left(E_{\mathrm{a}}+E_{\mathrm{g}}-\Delta E\right) / \mathrm{F} \\
& \simeq-L_{\mathrm{o}}-J+A+R+4.3 / \mathrm{F} \\
& \\
&+V_{\mathrm{fbp}}-E_{\mathrm{g}} / \mathrm{F}+\Delta E / \mathrm{F}
\end{aligned}
$$

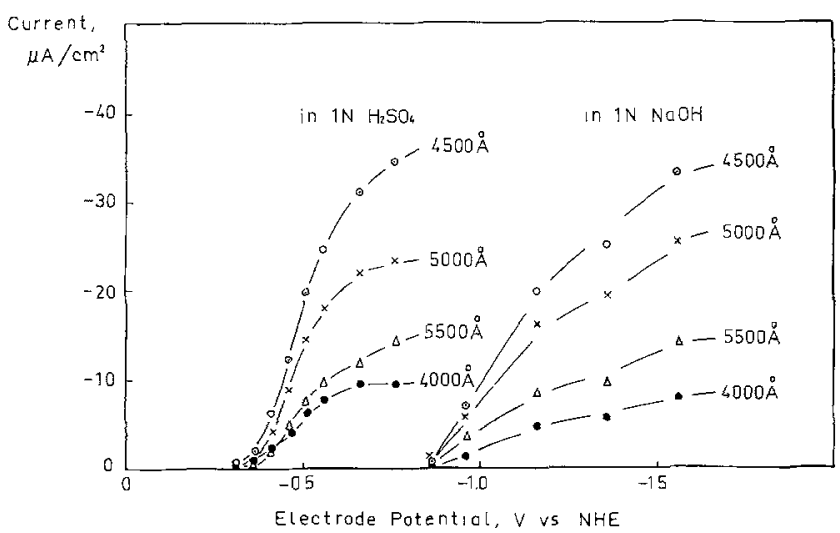

Fig. 9. The photocurrent-potential relations of $\mathrm{ZnTe}$ in $\mathrm{IN}$ $\mathrm{NaOH}$ and in $1 \mathrm{~N} \mathrm{H}_{2} \mathrm{SO}_{4}$ for light of several wavelengths.
Table IV. Slope of $\log i_{\mathrm{p}}-V$ relations

where $L_{0}, J$, and $R$ do not depend on semiconductor and the dependence of $A$ on the semiconductor is less than $0.1 \mathrm{eV}(27)$, Therefore, $\Delta H(e)$ is given by

$$
\Delta H(e) \simeq \text { const. }+V_{f b p}-E_{\mathrm{g}} / \mathrm{F}
$$

The probability of the existence of acceptors at energy $E, G(E)$, is given by

$$
G(E)=\exp \left(H(e)-E_{\mathrm{v}}\right) / k T
$$

where $E$ is the energy of the electrons at the surface at a potential $V$.

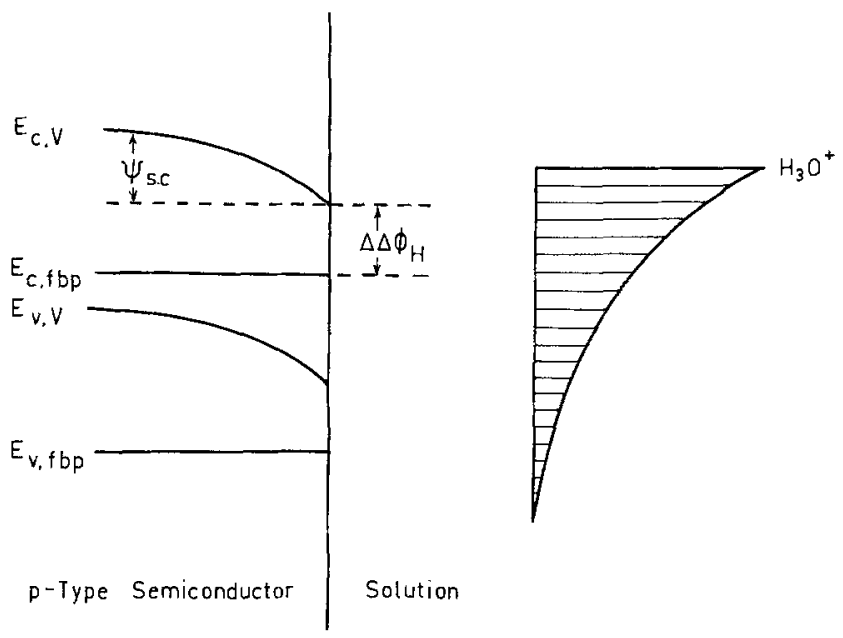

$$
\left\{\begin{array}{l}
v-v_{f b p}=\psi_{s . c}+\Delta \Delta \phi_{H} \\
\Delta \Delta \phi_{H}=\left(s \cdot c_{\Delta}^{s} \phi\right)_{v}-\left(s \cdot c_{\Delta}^{s} \phi\right)_{f b p}
\end{array}\right.
$$

Fig. 10. The schematic diagram of energy levels of the valence band and conduction band of a semiconductor and of an acceptor.

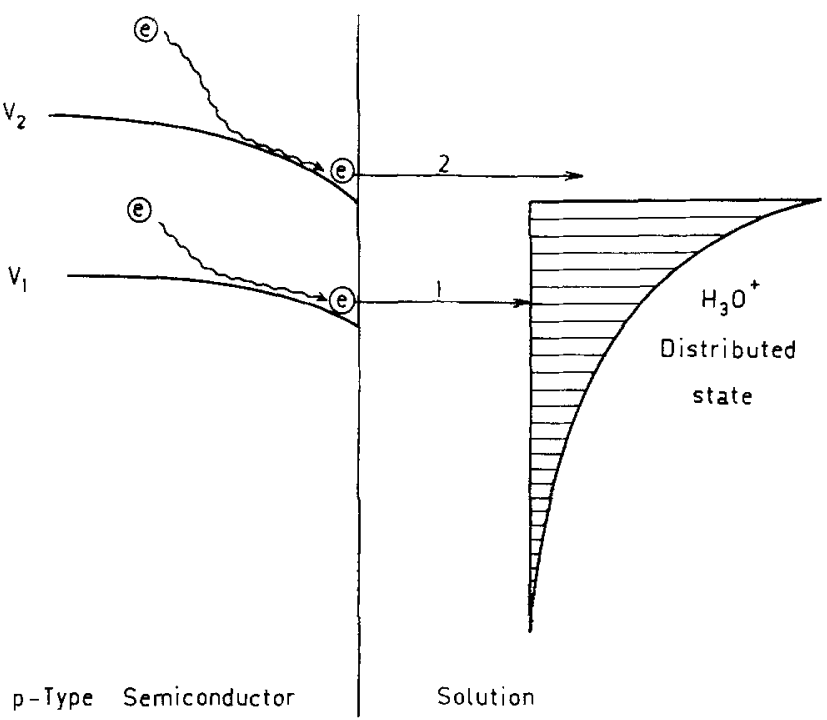

Fig. 11. Schematic illustration of the model proposed to describe the observed photocurrent behavior of semiconductor electrodes. 


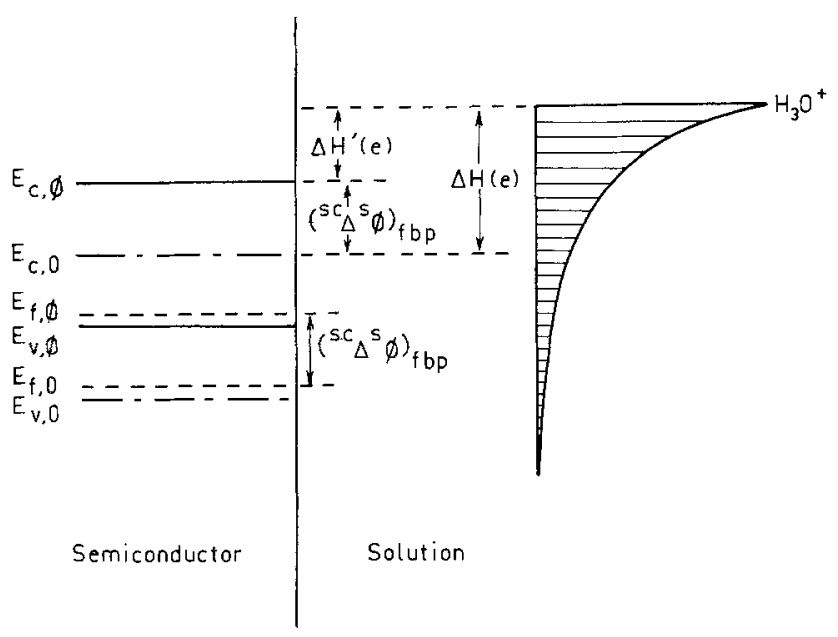

Fig. 12. The energy levels ot a semiconductor solution interface

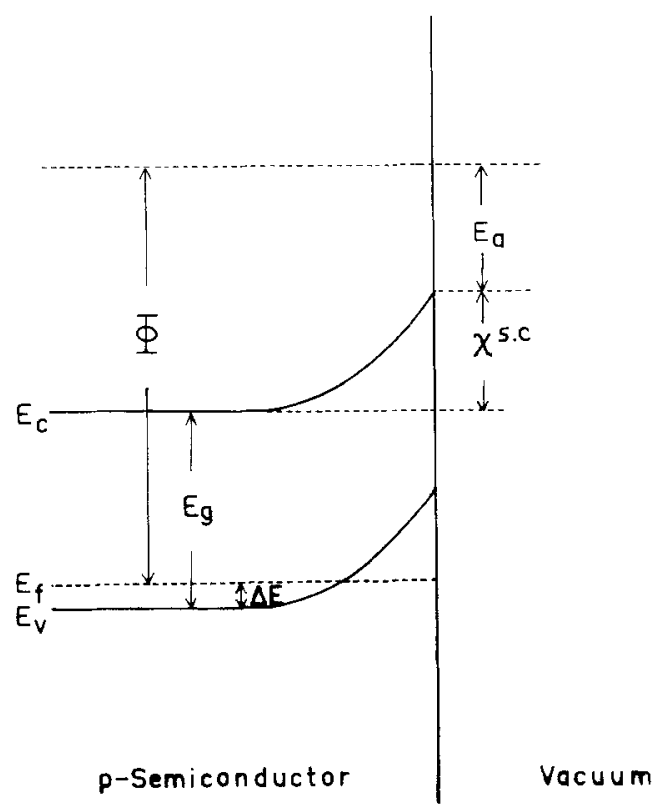

Fig. 13. Schematic diagram of the energy levels of a semiconductor with surface states in a vacuum.

$E_{\mathrm{v}}$ is given by

$$
E_{\mathrm{y}}=-\mathrm{F}\left(\mathrm{V}-\mathrm{V}_{\mathrm{fbp}}\right)
$$

where each of these potentials is on (e.g.) the N.H. scale. Therefore, $E_{\mathrm{V}}$ at the critical potential $E_{\text {crit }}$ is given by

$$
E_{\text {crit }}=-F\left(V_{\text {crit }}-V_{\text {fbp }}\right)
$$

At the critical potential, it can be assumed that $G(E)$ corresponds to an energy value of $0.1-0.2 \mathrm{eV}$ from the ground state of $\mathrm{H}_{3} \mathrm{O}^{+}$.

Therefore

$$
\Delta H(e) \bumpeq-F\left(V_{\text {crit }}-V_{f b p}\right)
$$

From Eq. [12] and [14], a linear relation between $\left(V_{\mathrm{fbp}}-E_{\mathrm{g}} / \mathrm{F}\right)$ and $\left(V_{\text {crit }}-V_{\mathrm{fbp}}\right)$ is expected. Figure 14 shows this relation. The relation shows the impor-

\begin{tabular}{|c|c|c|}
\hline Semiconductor & 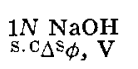 & $\begin{array}{l}1 N \mathrm{H} S O_{1} \\
\mathrm{~s} \cdot \mathrm{d}^{\prime} \phi, \mathrm{V}\end{array}$ \\
\hline $\begin{array}{l}\text { ZnTe } \\
\text { CdTe } \\
\text { GaAs } \\
\text { InP } \\
\text { GaP }\end{array}$ & $\begin{array}{l}-2.25 \\
-1.27 \\
-1.20 \\
-1.42 \\
-2.07\end{array}$ & $\begin{array}{r}-1.42 \\
-1.83 \\
-0.77 \\
-1.12\end{array}$ \\
\hline
\end{tabular}

Table V. Calculated values of the potential drop (volts) in the electric double layer at the flatband potential (see Eq. [10])
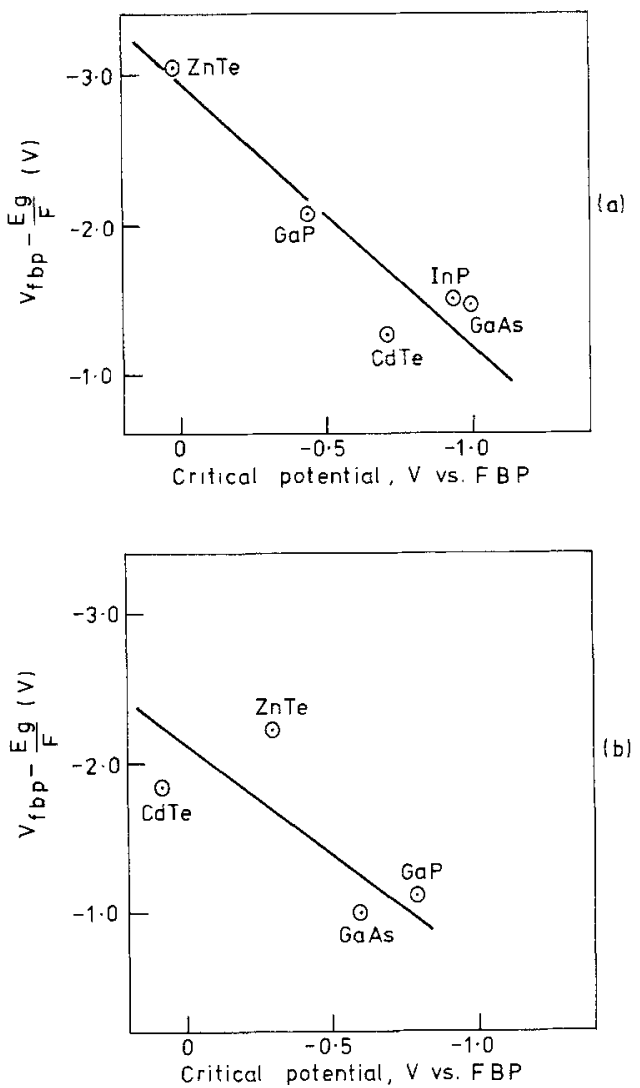

Fig. 14. The relations between $V_{f b p}-E_{g} / F$, and the critical potential with respect to the flatband potential in $1 \mathrm{~N} \mathrm{NaOH} \mathrm{(a)}$ and $\mathrm{IN} \mathrm{H}_{2} \mathrm{SO}_{4}$ (b).

tance of any energy gap in respect to the critical potential. Although a small energy gap is required from the point of solar energy absorption, the smaller the energy gap, the more negative the critical potential (with respect to the flatband potential) and, therefore, the smaller the efficiency of the hydrogen production.

The quantum efficiency-wavelength relation.-Quantum efficiency-wavelength relation shown in Fig. 4-6 exhibit two features. (i) The quantum efficiency wavelength relation passes through a maximum. (ii) The height of the maximum decreases as the potential becomes more positive and therefore nearer to the flatband potential.

The position of the maximum can be interpreted by considering the photocurrent $\left(i_{p}\right)$ as a function of the surface recombination.

Thus, $i_{\mathrm{p}}$ is given by

$i_{p}=f\left(i_{\text {electron arriving at surface }}\right)-f\left(v_{\text {surface recombination }}\right)$

As the wavelength decreases, the photon absorption increases and the number of electrons created per average photon increases and therefore the quantum efficiency. At sufficiently small wavelengths, the position of the average absorption of photons gets nearer to the surface. Hence, the effect of surface recombination will become more mportant and decrease the net current or quantum efficiency.

Stability.-The most outstanding differences in stability (Table III) are for $\mathrm{ZnTe}$ and CdTe.

Figures 15 and 16 (drawn for us by Dr. T. Ohashi) show the equilibrium potentials for several reactions relevant to $\mathrm{ZnTe}$ and $\mathrm{CdTe}$. For $\mathrm{CdTe}$, the equilibrium potential of hydrogen evolution at $\mathrm{pH}=$ 14 is more negative than that of the decomposition of CdTe. Hence, CdTe will not decompose in the potential range of hydrogen evolution. For $\mathrm{ZnTe}$, the equilibrium potential of hydrogen evolution is close to that of $\mathrm{ZnTe}$ decomposition. 
Transient behavior-Surface recombination.-The transient behavior may be due to either a process in the semiconductor or a process in the surface of the electrode, or a process in solution.

In the former case, the behavior would be due to time dependence of the electron concentration at the surface. The time constant is $10^{-3} \mathrm{sec}$ and could arise from the recombination process. Then, the number of excess electrons $t$ sec after illumination, $N(t)$, is

$$
N(t)=N\left(1-e^{-t / \tau}\right)
$$

where $N$ represents excess electrons at the steady state and $\tau$ is the lifetime of the excited electron. The num-

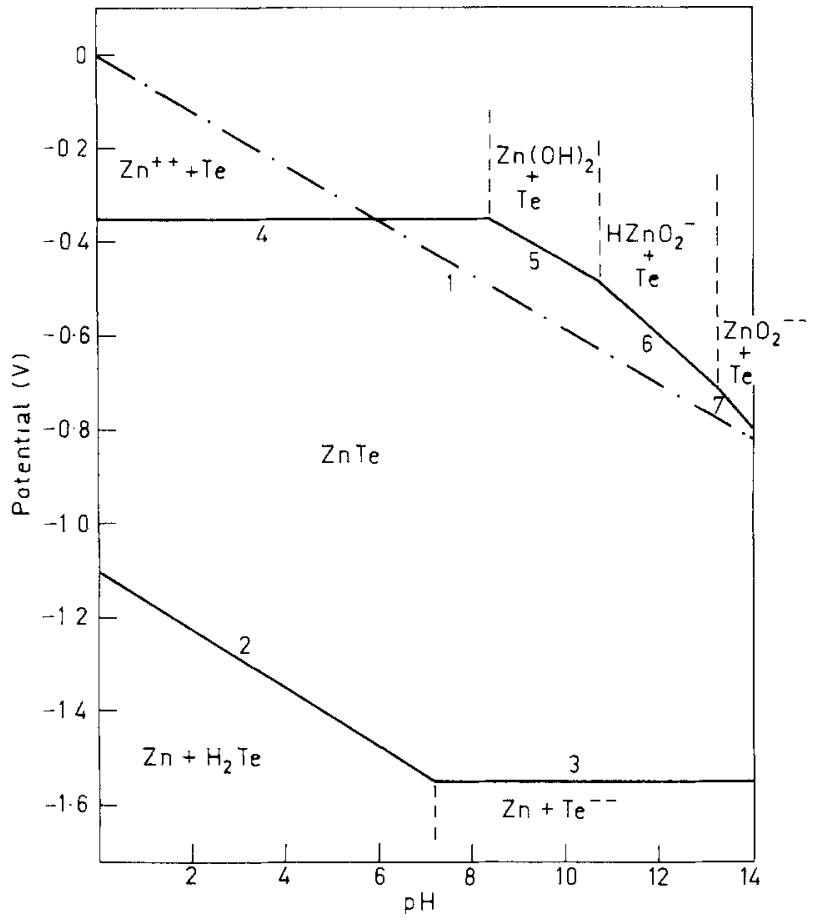

Fig. 15. Potential-pH equilibrium diagram for the system $\mathrm{ZnTe}$ water at $25^{\circ} \mathrm{C}$.

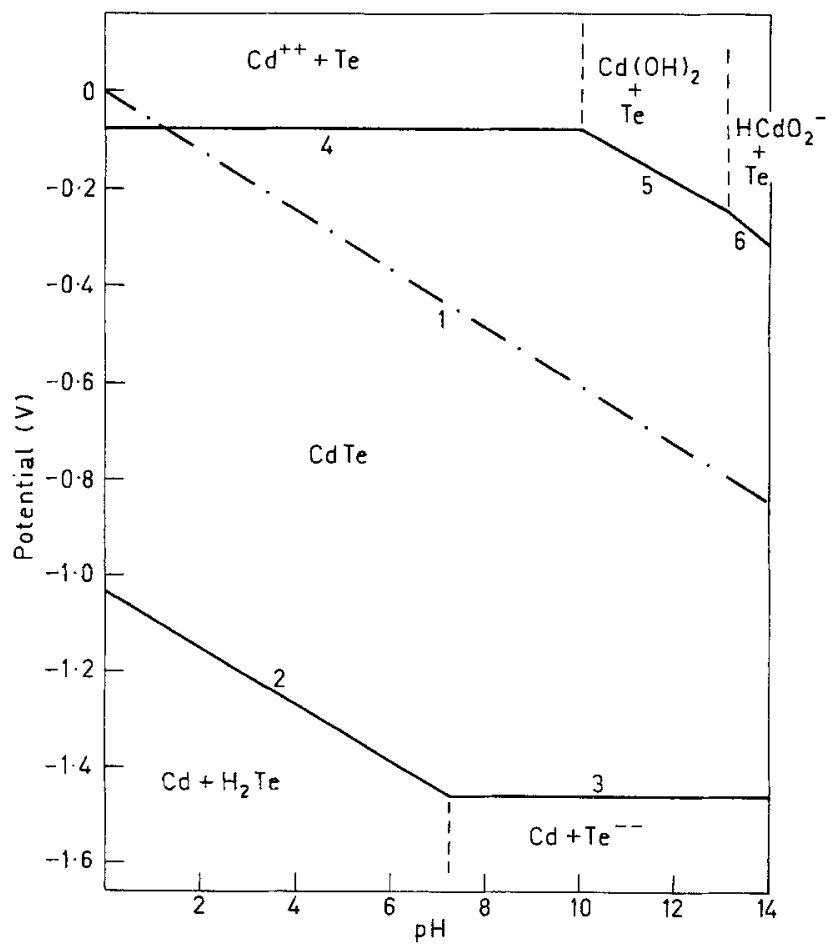

Fig. 16. Potential-pH equilibrium diagram for the system $\mathrm{CdTe}$ woter of $25^{\circ} \mathrm{C}$. ber of electrons $t$ sec after illumination is turned off, $N^{\prime}(t)$, is

$$
N^{\prime}(t)=N e^{-t / \tau}
$$

The time constant of diffusion is less than that of recombination process, so that

$$
N_{0}(t)=N_{0}\left(1-e^{t / \tau}\right)
$$

when the light is on and

$$
N_{0}^{\prime}(t)=N_{0} e^{-t / \tau}
$$

when the light is off, where $N_{0}$ is the steady-state concentration of excess electrons at the surface.

Since the photocurrent, $i_{\mathrm{p}}(t)$ is

$$
i_{\mathrm{p}}(t) \alpha N_{\mathrm{o}}(t)
$$

the time dependence of the photocurrent is

$$
i_{\mathrm{p}}(t)=i_{\text {st. }}\left(1-e^{-t / \tau}\right)
$$

with illumination on, where $i_{\text {st. }}$ is the steady-state photocurrent. Also

$$
i_{\mathrm{p}}(t)=i_{\mathrm{st} .} e^{-t / \tau}
$$

when the light is off.

The photocurrent according to Eq. [21] and [22] is shown in Fig. 17. The result of the behavior found in the present work was quite different from these predictions, especially when the electrode potential was near to the flatband potential (Fig. 17).

Hence, since the lifetime of excited electrons is $<10^{-8} \mathrm{sec}$, the transient behavior observed is due to surface electrochemical processes, such as the reduction of oxygen. Thus

$$
\begin{aligned}
& i_{\mathrm{p}}=i_{\mathrm{p}, \mathrm{H}_{2}}+i_{\mathrm{p}, \mathrm{red}} \\
& =k_{\mathrm{H}_{2}} \mathrm{CH}_{3} \mathrm{O}++k_{\mathrm{red}} \mathrm{C}_{\mathrm{red}}
\end{aligned}
$$

where $k_{\mathrm{H} 2}$ and $k_{\text {red }}$ are the rate constant for hydrogen evolution reaction and for some other reduction reaction, respectively.

Using Faraday's laws

$i_{\mathrm{p}}(t)=i_{\mathrm{p}, \mathrm{H}_{2}} \mathrm{C}_{\mathrm{H}_{3} \mathrm{O}}++k_{\mathrm{red}} \mathrm{C}_{\text {o,red }} \exp \left(-\frac{M}{\mathbf{F}} k_{\mathrm{red}} t\right)$

where $C_{0, \text { red }}$ is the concentration of the species to be reduced at time zero.

From Eq. [24], Iog $\frac{i(t)-i(\infty)}{i(0)}$ should be proportional to time, as shown in Fig. 18 [see also Ref. (28)].

\section{Acknowledgments}

We thang Mr. H. Kimura of Mitsubishi Electric Company Limited, Dr. O. Mizuno of Nippon Electric Company Limited, Dr. K. Akita of Fujitsu Laboratory

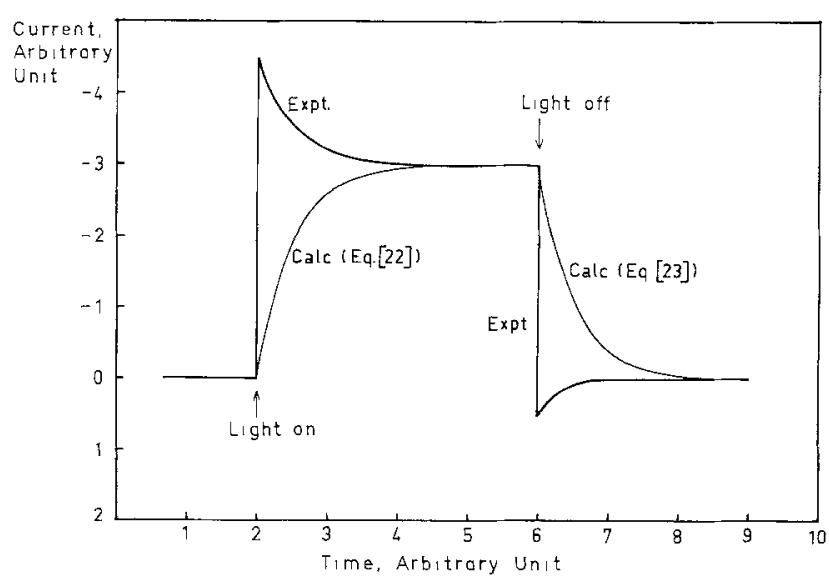

Fig. 17. Schematic diagram of the transient behavior of the current after illumination and interruption of light. 1, Equations [21] and [22]; 2, experimental. 


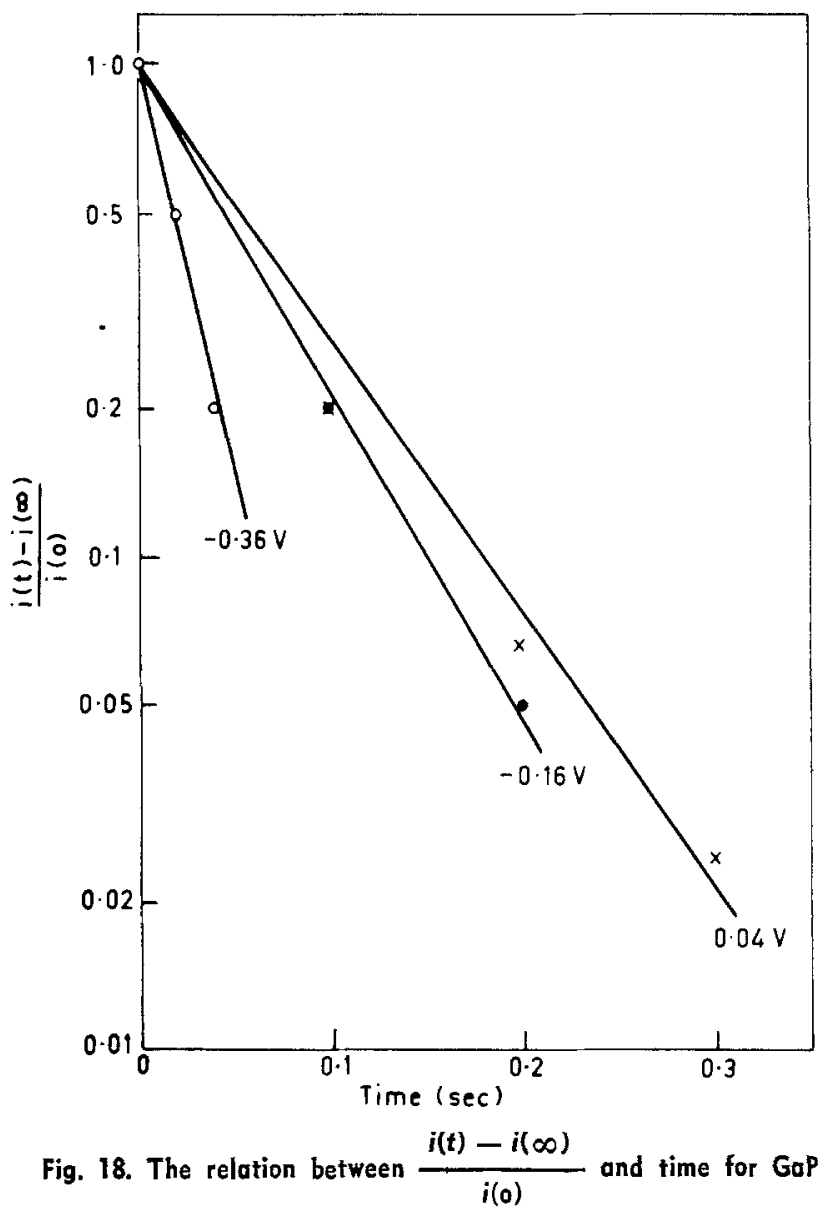

in $1 \mathrm{~N} \mathrm{H}_{2} \mathrm{SO}_{4}$.

Limited, Professor von Munch of Technical University of Hannover, and Toyo Silicon Company Limited for their donation of semiconductor single crystals. Thanks are due to Dr. K. Ohashi for discussion. One of us (K.U.) thanks Flinders University for its Flinders University Research Scholarship.

Manuscript submitted Dec. 13, 1976; revised manuscript received April 1, 1977.

Any discussion of this paper will appear in a Discussion Section to be published in the June 1978 Journal, All discussions for the June 1978 Discussion Section should be submitted by Feb. 1, 1978.
Publication costs of this article were assisted by Flinders University of South Australia.

\section{REFERENCES}

1. A. Fujishima and K. Honda, Nature (London), 238, 37 (1972).

2. W. Gissler, P. L. Lensi, and S. Pizzini, J. Appl. Electrochem., 6, 9 (1976).

3. A. J. Nozik, Nature (London), 25\%, 383 (1975).

4. M. S. Wrighton, D. S. Ginsley, P. T. Wolczauski, A. B. Ellis, D. L. Morse, and A. Lind, Proc. Natl. Acad, Sci., U.S.A., 72, 1518 (1975).

5. K. L. Hardee and A. J. Bard, This Journal, 122, 75 (1975)

6. A. Fujishima, K. Kohayakawa, and K. Honda, ibid., 122, 1487 (1975).

7. H. Yoneyama, H. Sakamoto, and H. Tamura, Electrochim. Acta, 20, 341 (1975)

8. H. Gerischer, Z. Elektrochem., 59, 9 (1954).

9. M. Sluyters-Rehbach and J. H. Sluyters, "Electroanalytical Chemistry: A Series of Advance," Vol. 4, A. J. Bond, Editor, chap. 1, Marcel Dekker, Inc., New York (1970).

10. W. D. Baker and A. G. Milnes, This Journal, 119, 1269 (1972)

11. V. I. Sapritskii and N. G. Bardina, Elektrokhimiya, $18,655(1972)$

12. H. C. Gatos and M. C. Lavine, Prog. Semiconductors, 9, 1 (1965)

13. M. Aven and W. Garwacki, This Journal, 114, 1063 (1967).

14. J. Lowen and R. H. Rediker, ibid., 107, 26 (1960).

15. O. Mizuno, Private communication.

16. H. Gerischer and I. Mattes, Z. Phys. Chem. (N.F.), $49,112(1966)$.

17. K. H. Beckmann and R. Memming, This Journal, 116, 368 (1969).

18. R. Memming and G. Schwandt, Electrochim. Acta, 13, 1299 (1968)

19. R. Memming, This Journal, 116, 785 (1969).

20. S. Mayumi, C. Iwakura, H. Yoneyama, and H. Tamura, Denki Kagaku, 44, 339 (1976).

21. H. Yoneyama, H. Sakamoto, and H. Tamura, Electrochim. Acta, 20, 341 (1975).

22. M. Gleria and R. Memming, J. Electroanal. Chem., 65, 163 (1975)

23. J. O'M. Bockris and A. K. N. Reddy, "Modern Electrochemistry," Vol. 2, chap. VII, Plenum Press, New York (1970)

24. A. R. Despic and J. O'M. Bockris, J. Chem. Phys., 32, 389 (1960)

25. S. Trasatti, J. Electroanal. Chem., 52, 313 (1974).

26. J. O'M. Bockris and S. O. Argade, J. Chem. Phys., 49, 5133 (1968).

27. J. O'M. Bockris and K. Uosaki. Adv. Chem. Ser., Am. Chem. Soc, In press (1976).

28. K. Uosaki, Ph.D." Thesis, The Flinders University of South Australia (1976) 